\title{
The Approach of Conflict Resolution Education to the Governance Management
}

\author{
Mujib Hasib \\ Universitas Muhammadiyah Makassar \\ Makassar, Indonesia \\ mujib_hasib@yahoo.com
}

\section{Dwi Dian Permatasari}

Universitas Muhammadiyah Makassar

Makassar, Indonesia

Dwidian_shasya@ymail.com

\author{
Muthia Mutmainnah Darmuh \\ Universitas Muhammadiyah Makassar \\ Makassar, Indonesia \\ muthiiamd@gmail.com
}

Zulfan Nahruddin

Universitas Muhammadiyah Makassar

Makassar, Indonesia

zulfannahruddin@gmail.com

\author{
Muchlas M. Tahir \\ Universitas Muhammadiyah Makassar \\ Makassar, Indonesia \\ muchlasmtahir7@gmail.com
}

\begin{abstract}
This study used a qualitative phenomenology approach thatis to describe and represent the experience of the informants about the conflict in Sub-Rappocini Makassar. Data analysis, data reduction, data presentation, drawing conclusions were cunducted. The results showed the police cooperated with various stakeholders to be alert to the commission of fights before the conflict occurred. Efforts performed by the police is the prevention of conflict, conflict cessation action and post-conflict recovery action. Democratization among the group caused by the lack of attention of local government. Local authorities agreed to take repressive stance against the perpetrators identified as trigger tensions and the outbreak of groups war. The resolution of conflicts was done unsystematically, and just explanation of the concept or knowledge of the conflict. The security forces still did not specifically provide guidance to constructively execute conflict resolution.
\end{abstract}

Keywords-Governance; conflict resolution; education.

\section{INTRODUCTION}

Conflicts often arise motivated by a variety of interests between certain groups and create instability in the order of a conflicted society Coser [1]. Conflict can be managed wisely to dominate social and constructive process for social change and does not represent violence. In the history of the world community, the conflict is often followed by other forms of violence, such as war and genocide [2].

According to Wiese and Becker [3] As for the background that led to the conflict, namely: (1) Individual differences that include differences in stance and feelings of each human being is a unique individual. Differences in feelings and stance against something or a real environment can be a factor causing social conflict, because in living social relations, one does not always go with the group. (2) The difference in cultural background forming different personalities. Thought and stance that will ultimately result in individual differences that can lead to conflict. (3) The difference between individual and group interests. Humans have feelings, stance and different cultural backgrounds. Therefore, at the same time, each person or group has different interests. (4). Rapid changes in value, and suddenly in the community. Change is a common and natural to happen, but if the change is rapid or even sudden, these changes will lead to social conflict.

Conflicts can be seen from two dimensions: 1). A perspective or point of view in which the conflict is considered always there and coloring all aspects of human interaction and social structure. 2). Open disputes such as war, revolution, strikes, movement and resistance. In connection with the condition of 
the Indonesian state which is so multi with all kinds of plurality and heterogeneity. Indonesia is a country that consists of a multi-ethnic and multicultural, even today Indonesia has become a multiparty state in the political system. This condition cannot prevent people from incidence of various forms of conflict [4]. Citizens in a democracy express their concerns peacefully and seek resolutions to problems that take into account common interest and recognize the human dignity of all involved [5]. Conflict resolution education provide the knowledge,abilities, and processes needed to choose alternative to self-destructive, violent behavior when confronted with interpersonal and intergroup conflict [6].

In Froom [7] the roots of violence in the mass behavior is a psychological trait caused by the perpetrators experiencing blunting guilt over their violent actions. Common sense removed and replaced with a weak morality away from the cultural context in which morality is built.

As several previous studies such as [8] findings show that first, it becomes very important, the creation of a space of interaction for young people by giving the value of the materials related to religious pluralism and multiculturalism as a stimulus to the development of perception and attitude. Secondly, a strategic effort to raise awareness of school age youth for peace in Poso is to develop the spirit of religious pluralism and tolerance in the diversity of cultures in which each sub-culture no matter how small should be respected and given equal rights with the more dominant culture. Third, in the perspective of education for adolescent communication, conflict resolution is done through instructional models, interactional and transactional. The results of the study [9] communication has less role in resolving conflicts in the village Sendangan Among adolescents, Kakas sub-district in a sense because of lack of involvement of the communication, it hence cannot resolve the conflict. Therefore, the spirit of the novelty of this study is to see the settlement of the conflict through conflict resolution approach education from the perspective of governance governance.

\section{METHODOLOGY}

This study used a qualitative approach with a research procedures that produce descriptive data in the form of words written or spoken of people and observed behavior [10]. This research type of phenomenology of explaining and describing the experience of the informants about the conflict in
Sub Rappocini Makassar. To collect primary data and secondary data the researchers used several data collection techniques by using the interview guides as a handle of researchers after the data analysis techniques do data reduction, data presentation, drawing conclusions [11].

\section{FINDINGS AND DISCUSSION}

\section{Youth Inter-group Conflict Governance In Rappocini Makassar.}

According to the interviews that authors obtained that become apparent in local government regulations no. 22015 on local regulations, laws No. 7 of 2012 on the regulation of social conflict handlers are expected to protect and give security to the people in Rappocini Makassar. In this section the authors developed a description of the instruments interviews and field data relating to the subject matter. Moreover, the authors also found a link among the city government with the police to work together to deal with a case of fighting between these groups.

Reviewing conflicts between youth groups occurred in the District Rappocini pose a riddle from the resolution of conflict resolution between the two groups involved in the conflict. Conflict management is the key to determine the extent of the settlement process that has been undertaken by the Government of Makassar in this case the police, as agency that works to maintain security and order in the city, so that the potential conflict of aftershocks in Rappocini can be resolved to the root of the problem.

Because the village government cannot do much to resolve the conflict, authors would do more indepth interview by these bodies within the scope of Makassar city administration related social behavior of society and government security itself. The agency is the office of the city of Makassar social services and the police in this case Polsekta Rappocini. Here is a description of the governance approach to the conflict do these institutions in dealing with fights between groups.

Conflict Between Youth Groups in the District Rappocini is the duty of the police themselves. However, apart from the pattern of conceptual and preventive actions, police also entered into agreement with several parties to be aware of the commission of a fight before the conflict occurred. Therefore, the government wards and district joint police agencies (police Rappocini), work together to seek ways of handling cases of conflict between groups of youth on the street Kandea. 
According to the interview that authors obtained which is apparent in government No 102015 on the regulations in the area of Law No. 7 of 2012 concerning the regulation of social conflict security can protect and give security to the people.

Fights between youth groups often occur in Sub Rappocini because it is not the creation of Democratization and high rates of unemployment, abandoned children for school dropouts in the district Rappocini. Indirectly addressing the issue of fighting between groups, but the Social Service turned out to deal with criminals who are also perpetrators of fights between groups in society. Social Office then classify some categories of children who are considered abandoned and mischievous. At least in this discussion we can see that the perpetrators of conflict between groups of youth in the District Rappocini Makassar.

\section{Reconciliation Approach}

In charge of social issues, such as youth conflict, reconciliation approach is done in the form of Social Services Rehabilitation Delinquency Children and Adolescents. Social rehabilitation itself in understanding the recovery process of selfesteem, awareness, and social responsibility juvenile offenders so free from delinquency act appropriately. While juvenile delinquency is deviant behavior or violate the values and norms of society. These activities made for their naughty children and adolescents who are considered potentially committing or has committed a crime including one follow-fights between groups that often they do.

Parents and their social environment are also included in this program as a peer environment, the District Rappocini or work environment and family and neighbors. For those naughty children and teenagers are involved in this program is more often referred to as the victim. Therefore, it could mean that there is a cause demage on their mental and social value.

This is the beginning of the rehabilitation program in this section, will be preceded by an orientation and consultations involving the Government of Makassar, Social Service itself, the Department of Education, Department of Health, Ministry of Religious Affairs, Ministry of Justice, Ministry of Labor, universities in Makassar, NonGovernmental Organization (NGOs), community leaders and parents of the children involved. This stage into the stage of the search process support and assistance from the city government and related agencies. After receiving support, proceed to the stage of identifying potential victims to be rehabilitated.

In accordance with the above interview, the data that has been obtained is then analyzed and classified, after that visit to the victim's home / clients do but there are also observations made to the victim's residence environment. Meet potential victims / clients certainly found several problems including the reluctance of prospective clients to follow a rehabilitation program. It usually will carried motivation and awareness efforts for prospective clients, for example by meeting directly or talk with their parents.

Governance conflicts between groups of youths in the district Rappocini has become the responsibility of the city government through the agencies that did not connect with the issue of the conflict handler, Social Service.

Governance made by the two institutions are already apparent based on the portion of each various concepts that have been realized as it has done for National Unity party, namely the postconflict preventive efforts and investigations in order to counter potential subsequent conflicts by directing the target location to conflict including the perpetrator and the victim konflict while the concept realized by the Social Service is to realize the concept of Social Rehabilitation Service Delinquency and youth has also conducted awareness of legal regulations on Conflicts in the form of seminars and participants, drawn directly from the citizens Baraya especially youth groups indicated both involved or potentially involved in the conflict.

Fighting between the groups was not received attentiom. When a fight occurs only once does not affect the government bad image, then the behavior was seen as something innocuous, but when fights in a region occur repeatedly and lead to bad seal of government in power in the region then fights get noticed. Factional fighting among the youth in the district Rappocini endless allowed the government agreed to take repressive measures. Repressive, meaning that a given reaction to the events of the crime by the public through law enforcement agencies (police, prosecutors, courts, and correctional institutions), as well as giving a negative reaction to the perpetrators. Law enforcement agencies include police agencies, prosecutors, court / judicial, and correctional institutions. While the official institution responsible for crime prevention is the police agencies (but because of the limited facilities and 
infrastructure owned police agencies, the public participation is needed to help eradicate crime) Local authorities agreed to take repressive stance against the perpetrators who have been identified as a trigger tensions and the outbreak of war on the group.

\section{Approach Conflict Resolution Education.}

Subdistrict Rappocini as a social subsystem was not free of conflicts between residents, especially the conflicts experienced by youth groups. Conflicts in the form of a youth group and interpersonal conflicts between groups in general is a conflict in the special problems and conflicts in the patterns of social interaction and not until the conflict is structural. Most of the youth group conflict is purely horizontal, occurring between groups of youth themselves, and only a small portion of their conflict that is the vertical that occurs between teachers and youth group leaders Rappocini subdistrict. Conflict between groups of youth, which is mainly driven by the nonfulfillment of their psychological needs, stretching from simple conflict, such as psychological hostility and social tension, until the conflict that leads to physical violence.

Groups of young men involved in violent conflict are indeed small, but its cause cannot be ignored. Conflicts experienced by youth groups have turned out a negative impact on the psychological condition, social relationships youth groups, learning climate in District Rappocini, and the salvation of their souls. Secondly, only some youth groups have been able to resolve their own simple horizontal conflicts through compromise.

But for other conflicts, some youth groups tend to use the strategic settlement of the conflict unconstructively, by withdrawing from the conflict, with harbored in him, which can actually cause their mental health disorders. A small part of other youth groups even tend to resolve conflict in a manner opposed to the opposing party, which is sometimes accompanied by acts of violence. Conflict resolution through problem solving (problem solving) toward win-win solutions tend not many use-right by the youth group. Meanwhile, the dependence of the youth group to others, particularly those with authority in the District Rappocini, in resolving the conflict is still high.

Teaching concerning the resolution of conflicts in Sub Rappocini seeds have actually existed, the conflict resolution carried unsystematically, and only a limited explanation of the concept or knowledge of the conflict. The security forces are still not specifically fostering the knowledge, attitudes, skills to carry out the resolution of conflicts constructively to the youth group.

Implementation of Conflict Resolution with socialization approach that integrates seamlessly with the container creations of young people towards the resolution of the conflict into a more positive direction. The attitude of the youth group to conflict resolution is more positive than the attitude of youth groups before following the implementation of the model. A more positive attitude towards the conflict resolution adds to the competence of citizens, especially in terms of attitude of the citizens.

A positive attitude towards the resolution of this conflict means youth groups do not tend to view conflict as something negative. They then have a more positive tendency to resolve their own conflict and help resolve the conflict of others in a way that is peaceful, democratic and constructive, not through violence, towards solving the problems that are equally beneficial (win-win problem solving).

\section{CONCLUSION}

Especially its security approach to police and entered into a collaboration with several parties to be aware of the commission of a fight before the conflict occurred. Efforts performed by the police is the prevention of conflict, conflict termination action and post-conflict recovery action. Democratic approaches are directed to shutter Governance Conflict between Youth Groups in District Rappocini Makassar City becomes a crucial thing because the real condition of the study sites, the District Rappocini. Democratization among the group due to lack of attention of local government especially activities that are able to tighten the brotherhood between youth groups in sub Rappocini. Reconciliation approach is done in the form of Social Services Rehabilitation Delinquency Children And Adolescents. Factional fighting among the youth in the district Rappocini endless allowed the government agreed to take a repressive attitude. Local authorities agreed to take repressive stance against the perpetrators who have been identified as a trigger tensions and the outbreak of war the group. Education regarding the resolution of conflicts in Sub Rappocini seeds have actually existed, the conflict resolution is done unsystematically, and only a limited explanation of the concept or knowledge of the conflict. The security forces are still not specifically fostering the knowledge, attitudes, skills to carry out the 
resolution of conflicts constructively to the youth group.

\section{REFERENCES}

[1] Susan, Novri. "Negara gagal Mengelola Konflik (Demokrasi Dan Tata Kelola Konflik di Indonesia)”. Yogyakarta: Penerbit Kopi: sleman 55571, 2012.

[2] Susan, Novri. Pengantar sosiologi politik dan isu-isu Konflik Kontemporer.: Rawamangung- Jakarta: Kencana Prenada media Group, 2014.

[3] Nurita. "Peran Komunikasi antar budaya masyarakat dalam menyelesaikan konflik di perumahan tamang sari kota samarinda". E-Jurnal Ilmu Komunikasi, Volume 2 Nomor 4, 2014.

[4] Ahmad, Z. "Perbandingan peningkatan kemampuan koneksi matematis siswa SMP antara yang mendapatkan pembelajaran menggunakan strategi konflik kognitf piaget dan hasweh". Bandung: UPI, 2014.

[5] Crawford, D \& Bodine, R."Conflict Resolution education A Guide to implementing programs in schools, youth-serving organization, and community and juvenile justice settings". Safe and drugfree School program. USA: Department of Education, 1996.

[6] Agricola, Geertje. "Designing Conflict Resolution Education: Educational Design and Consultancy". Utrecht: Utrecht University, 2009.

[7] Froom. “Akar Kekerasan”, Yogyakarta: Pustaka Pelajar, 2013.

[8] Khairil, Muhammad. "Resolusi Konflik Poso Dalam Perspektif Komunikasi Pendidikan Berbasis Agama Dan Budaya". Jurnal Analisis, Volume XII, Nomor 2, 2012.

[9] Lompoliu, A. Pasoreh, Yuriwaty. "Peran Komunikasi Dalam Menyelesaikan Konflik Diantara Remaja Di Desa Sendangan Kecamatan Kakas”. journal Acta Diurna Volume IV. No.3. Tahun 2015, 2015.

[10] Moleong, Lexy. "Metode Penelitian Kualitatif”. Bandung: Remaja Rosda Karya, 2014.

[11] Sugiyono. "Memahami Penelitian Kualitatif". Bandung : ALFABETA, 2012 